\title{
Stenotrophomonas, a New Bacterial Genus for Xanthomonas maltophilia (Hugh 1980) Swings et al. 1983
}

\author{
NORBERTO J. PALLERONI ${ }^{1 *}$ AND JOHN F. BRADBURY ${ }^{2}$ \\ Department of Microbiology, New York University Medical Center, 550 First Avenue, \\ New York, New York, 10016, ${ }^{1}$ and International Mycological Institute, Egham, \\ Surrey TW20 9TY, United Kingdom ${ }^{2}$
}

\begin{abstract}
In consideration of the criticisms of the transfer of Pseudomonas maltophilia to the genus Xanthomonas proposed by J. Swings, P. De Vos, M. Van den Mooter, and J. De Ley (Int. J. Syst. Bacteriol. 33:409-413, 1983), a new generic name is created for this taxon. The name Stenotrophomonas is here proposed for the new genus, which includes a single species, Stenotrophomonas maltophilia. This proposal restores the genus Xanthomonas to its former definition (J. Bradbury, p. 199-210, in N. R. Krieg and J. G. Holt, ed., Bergey's Manual of Systematic Bacteriology, 1984) The arguments on which this proposal is based are presented.
\end{abstract}

As a result of the work of Swings et al. (28), in confirmation of previous findings (24), the two members (Pseudomonas maltophilia and Xanthomonas spp.) of group $\mathrm{V}$ of Pseudomonas described by Palleroni (20) were placed together under the generic name Xanthomonas. This decision did not receive universal approval $(20,21,23)$, mainly because the two taxa differ in many basic properties that would justify different generic allocations. The problem was recently analyzed in depth by Van Zyl and Steyn (32), who shared this criticism. In what follows, we review the properties of the genus Xanthomonas and of the species Xanthomonas maltophilia in order to justify a proposal of a new genus for the latter.

Characteristics of the genus Xanthomonas. Following a suggestion by Burkholder (2), Dowson (4) created the name Xanthomonas for a well-defined subgroup of yellow-pigmented phytopathogenic pseudomonads which had been placed together with many other unrelated bacteria in the genus Phytomonas. Dowson (4) defined Xanthomonas as follows: "non-sporing, rod-shaped bacteria. Gram-negative, motile by one polar flagellum (rarely 2 present), or nonmotile, yellow in the mass on nutrient agar and on sterile potato, on both of which abundant slimy growths are formed. Most species digest starch and produce acid in lactose; none produces acid in salicin." Two corrections were made later by Dowson: deletion of nonmotility and a change from nutrient agar to nutrient glucose agar (5).

In subsequent definitions of the genus, the following characteristics were added: absence of poly- $\beta$-hydroxybutyrate inclusions, production of highly characteristic brominated aryl-polyene yellow pigments (xanthomonadins), infrequent production of a diffusible, brown color in beef extract agar, digestion of proteins, production of hydrogen sulfide, inability to use asparagine as the sole source of carbon and nitrogen, absence of denitrification and of nitrate reduction, negative or weak oxidase reaction, inhibition of growth by $0.1 \%$ (and frequently by $0.02 \%$ ) triphenyltetrazolium chloride, requirement for growth factors (usually methionine, glutamic acid, nicotinic acid, or a combination of these), optimal growth temperature of 25 to $27^{\circ} \mathrm{C}$, DNA base composition ( 63 to $71 \mathrm{~mol} \% \mathrm{G}+\mathrm{C}$ ), and plant pathogenicity. Thus far, presence of pili has not been reported for any of the species (1). The slimes produced by various

\footnotetext{
* Corresponding author.
}

species and pathovars were identified as anionic exopolysaccharides, to which the common name "xanthan gums" has been applied. These compounds have very interesting properties and may play a role in the interactions of the pathogens with their respective plant hosts (17). As pointed out by Dye (6), these organisms "form a well-defined remarkably uniform group from which other yellow-pigmented, Gramnegative, monotrichous, aerobic, non-sporing organisms can be distinguished in the laboratory without difficulty."

In Bergey's Manual of Systematic Bacteriology (1), five well-characterized species ( $X$. campestris, $X$. fragariae, $X$. albilineans, $X$. axonopodis, and $X$. ampelina) are described; one of these, $X$. campestris, is subdivided into many pathovars that are named according to the host plant of origin. The five species accepted by Bradbury (1) were those already included in the 8th edition of Bergey's Manual of Determinative Bacteriology (8), but a sixth species of doubtful affiliation $(X$. populi) was added. For the list of pathovars, Bradbury accepted the one given by Dye et al. (7) and added only two.

A review of the genus Xanthomonas was included in the first edition of the treatise The Prokaryotes: a Handbook on Habitats, Isolation and Identification of Bacteria (26). Unfortunately, aside from a summary of the general properties of Xanthomonas spp. by Palleroni (22), the special chapter on this important genus of gram-negative phytopathogens has been omitted from the second edition of the treatise.

Characteristics of $\boldsymbol{P}$. maltophilia. $\boldsymbol{P}$. maltophilia was named by Hugh and Ryschenkow (12) and later described in detail by the same authors (13). The name, accidentally omitted from the Approved Lists of Bacterial Names (24a), was revived by Hugh (10). Many additional phenotypic properties were added by Stanier et al. (25) in their extensive characterization of Pseudomonas species; these authors found $P$. maltophilia to constitute a very uniform taxon. The colonies of these organisms differ markedly in color and general appearance from the slimy, brightly yellow ones that are characteristic of many Xanthomonas strains. They may be faintly yellow, probably because of flavins (25). $P$. maltophilia strains have been isolated from very diverse materials, including plants, but they do not seem to have phytopathogenic propensities. However, this property has not been critically investigated. The properties of the strains are described in detail below, under the new genus name Stenotrophomonas.

Transfer of $\boldsymbol{P}$. maltophilia to the genus Xanthomonas. De- 
spite the global resemblance of Xanthomonas and Pseudomonas spp. in their basic phenotypic properties, there was hardly any reason to suspect a priori any relationship between Xanthomonas spp. and any of the Pseudomonas species in particular. It must be admitted, however, that studies of the two taxa have not followed the same methodology, and therefore many details of the phenotypic descriptions cannot be subjected to comparison.

Murata and Starr (18) showed that there was very little overlap between the Pseudomonas species described by Stanier et al. (25) and Xanthomonas species, when the organisms were analyzed by the so-called "segmental DNA homology" procedure. However, a possible exception was $P$. maltophilia, which was found to be marginally related to Xanthomonas species. These results were the main reason for the inclusion of Xanthomonas strains by Palleroni et al. (24) in their work on similarities of rRNA cistrons by hybridization methods among pseudomonads. These studies clearly demonstrated a relationship between $P$. maltophilia and Xanthomonas spp. at the level of their rRNA gene sequences. Ten years later, Swings et al. (28) confirmed the relationship by using DNA-rRNA hybridizations and made their proposal to transfer $P$. maltophilia to the genus Xanthomonas.

From an examination of the properties of the two taxa, it is clear that $P$. maltophilia cannot be moved effortlessly into the genus Xanthomonas without a substantial redefinition of this genus. Consequently, the proposal by Swings et al. (28) has not been universally accepted. Basic objections are the inconvenience of defining bacterial genera mainly on the basis of molecular criteria, which implied in this particular case the tacit dismissal of a group of excellent characteristics for generic differentiation $(20,21)$.

Critical analysis of the transfer of $P$. maltophilia to the genus Xanthomonas. Recently, a most thorough analysis of this unsettled situation was published (32). Some of the arguments clearly point to the inconvenience of transferring $P$. maltophilia to the genus Xanthomonas, and they are summarized below. The original article should be consulted for more detail and as a source of references.

(i) There are many phenotypic differences between $P$. maltophilia and members of Xanthomonas. These include the type of flagellation, pigment production, nature of extracellular polysaccharides, optimal growth temperature, nitrate reduction, acid production from carbohydrates, starch hydrolysis, pathogenicity, resistance to antibiotics and other deleterious agents, and a substantial number of miscellaneous properties, all of which suggest more profound genomic differences than those normally distinguishing species of the same genus.

(ii) Both taxa vary in fatty acid composition, while ubiquinones with eight isoprene units are not limited to them but are found elsewhere in the family Pseudomonadaceae. These two criteria do not seem to give much support to the proposal.

(iii) The G+C content of the DNA of $P$. maltophilia falls within the range for Xanthomonas species, but similarities in DNA base composition can only be added to other criteria in support of presumed synonymy and are not valuable in themselves.

(iv) Perhaps more significantly, there are discrepancies among the results reported by workers of the same laboratory $(3,28)$ for identical strains. The melting temperature range of the hybrid nucleic acid molecules (one of the main criteria used by these workers for taxon circumscription) appears to have been expanded mainly with the intention of accommodating $P$. maltophilia within the redefined genus Xanthomonas. It should be added that the similarity maps drawn by De Vos and De Ley (3) reinforce the idea of similarity, but not identity, of $P$. maltophilia and species of Xanthomonas.

Swings et al. (28) have calculated the similarity coefficient, $S_{\mathrm{SM}}$, between $X$. maltophilia and other Xanthomonas species as $75 \%$. In a comparative study carried out by Van Zyl and Steyn (31), an even higher value (79\%) was obtained, but the relationship was lower than with the majority of Pseudomonas strains included in the study.

Additional comments on another article from the same laboratory deserve consideration here. Van den Mooter and Swings (29) reported a numerical analysis of 295 phenotypic traits of 266 Xanthomonas strains, of which 7 were labeled as $X$. maltophilia. Of these, five were authentic representatives of the species and two (the type strains of $P$. betle and of $P$. hibiscicola) were added because, in the authors' opinion, they seem to be members of the same phenon. The $S_{\mathrm{SM}}$ between this phenon and other Xanthomonas phena was calculated as $65 \%$.

It is our opinion that this extensive study gives only limited support to the transfer of $P$. maltophilia to the genus Xanthomonas for the reasons summarized below.

(i) The strains of $P$. maltophilia are described as negative for the capacity of growth at the expense of glucose, mannose, fructose, sucrose, trehalose, maltose (for which the species was originally named), cellobiose, D-alanine, $\mathrm{L}$-alanine, and L-glutamic acid. The explanation that is given for these anomalous results with these substrates of high diagnostic value is that L-methionine had not been added as a growth factor to the basal medium used in the experiments. In fact, the addition of L-methionine would have made it possible to obtain nutritional data not only for the authentic $P$. maltophilia strains but also in support of the proposed synonymy of the three species lumped in this phenon. For instance, we do not know whether the two additional strains actually use the disaccharides characteristic of the nutritional spectra of authentic $P$. maltophilia. Moreover, it is very probable that the small amount of L-methionine required as a growth factor would have had little effect on the behavior of the nonexacting species.

(ii) In spite of the lack of a growth factor in the medium, the strains of $X$. maltophilia are reported in the article to be capable of growth on succinate, fumarate, malate, citrate, acetate, lactate, and propionate, all of which are qualified by the authors as having diagnostic value. Aside from the fact that the utilization of these organic acids is hardly diagnostic, in view of the fact that many other pseudomonads readily utilize them (25), one obvious question is whether the strains grow on these organic acids in a medium unsupplemented with L-methionine. There are no comments in the article about these anomalies.

(iii) It is also reported in the article that $X$. maltophilia was "shown to have xanthomonadin, justifying [its] inclusion in the genus." Reference is made to Starr et al. (27), who clearly state that "the pigments of the pale yellow $P$. maltophilia ... are not xanthomonadins.",

(iv) Data are presented in the article in percentages of positive strains, and therefore it is impossible for the reader to reconstruct the phenotype of individual strains. This is perhaps justifiable when one deals with many strains, but in this case there were only seven strains, of which five were authentic. We are informed that $71 \%$ of the strains (that is, five) were found to have oxidase activity and to grow at $37^{\circ} \mathrm{C}$ and that one strain (14\% of 7 ) produced slimy colonies, but 
TABLE 1. Differences between $S$. maltophilia and Xanthomonas spp.

\begin{tabular}{|c|c|c|c|}
\hline \multirow[b]{2}{*}{ Characteristic } & \multicolumn{2}{|c|}{ Result for ${ }^{a}$ : } & \multirow[b]{2}{*}{ Reference(s) } \\
\hline & S. maltophilia & $\begin{array}{l}\text { Xanthomonas } \\
\text { spp. }\end{array}$ & \\
\hline No. of flagella & $>1$ & 1 & 1,13 \\
\hline Fimbriae & + & - & \\
\hline Xanthomonadins & - & + & 26 \\
\hline Xanthan gums & - & + & 1 \\
\hline $\begin{array}{l}\text { Asparagine as a } \mathrm{C} \text { and } \mathrm{N} \\
\text { source }\end{array}$ & + & - & 31 \\
\hline Nitrate reduction & $(+)^{b}$ & - & 13 \\
\hline $\begin{array}{l}\text { Inhibition of growth by } \\
0.1 \% \text { TPTC }\end{array}$ & - & $+^{d}$ & 1 \\
\hline Starch hydrolysis & - & $\mathrm{V}^{e}$ & 1,20 \\
\hline Chitin hydrolysis & + & - & $9 a$ \\
\hline Growth at $37^{\circ} \mathrm{C}$ & + & - & 13,20 \\
\hline Oxidase reaction & $(+)$ & $(-)$ & 1,20 \\
\hline Plant pathogenicity & - & + & 1 \\
\hline $\begin{array}{l}\text { Association with human } \\
\text { infections and clinical } \\
\text { specimens }\end{array}$ & + & - & 11 \\
\hline $\begin{array}{l}\text { Growth in the presence of } \\
0.01 \% \text { methyl green, } \\
\text { thionin, or lead acetate }\end{array}$ & + & - & 28 \\
\hline $\begin{array}{l}\text { Resistance to tetracycline, } \\
\text { kanamycin, and } \\
\text { erythromycin }\end{array}$ & + & $-f$ & 30 \\
\hline Resistance to novobiocin & + & $-g$ & 30 \\
\hline
\end{tabular}

${ }^{a}$ Parentheses indicate that the result applies to the majority of the strains.

${ }^{b}$ Nitrate not used as a nitrogen source.

${ }^{c}$ TPTC, triphenyltetrazolium chloride.

${ }^{d}$ Frequently inhibited by $0.02 \%$ TPTC.

e $\mathrm{V}$, variable.

$f 97 \%$ of the strains tested are sensitive.

$g$ Only $X$. albilineans is resistant.

we are not told anything about the identities of the positive strains. Again, these points are worth clarification, in view of the allegation that the type strains of two species $(P$. betle and $P$. hibiscicola) are members of the species $P$. maltophilia.

In view of the above, the article by Van den Mooter and Swings (29) does not contribute solid evidence in support of the inclusion of $P$. maltophilia in the genus Xanthomonas.

Similarities between the two taxa. Aside from similarities in the sequences of rRNA cistrons, $P$. maltophilia and Xanthomonas spp. show resemblances in the utilization of certain substrates (although this point has not been exhaustively explored for Xanthomonas species), in the hydrolysis of Tween 80 , in the sensitivity to some phages, and, more importantly, in details of the composition of the cell envelopes (19). However, in our opinion the differences outweigh the resemblances. At present, there is little difficulty in identifying $P$. maltophilia and Xanthomonas strains isolated from nature, although, to some extent, there may be some overlap in their natural habitats. As mentioned by Van Zyl and Steyn (32), after an improved characterization of Xanthomonas spp. has been achieved $(29,33)$, inclusion of $P$. maltophilia in the genus Xanthomonas, far from promoting taxonomic stability in this genus, will lead to confusion and will complicate the task of classifying and identifying isolates of the species.

Proposal of a new genus, Stenotrophomonas, for the species $X$. maltophilia. In view of the reasons expressed above, we propose to transfer $X$. maltophilia to the new genus
Stenotrophomonas (Ste.no.tro.pho.mo'nas. Gr. adj. stenus, narrow; Gr. n. trophus, one who feeds; Gr. n. monas, a unit, monad; M.L. fem. n. Stenotrophomonas, a unit feeding on few substrates). In the analysis by Stanier et al. (25) of many strains of $P$. maltophilia, it was found that they had a very limited nutritional spectrum, and this is reflected in the proposed new name. The proposal of the new genus name restores the genus Xanthomonas to its original definition (1).

The following is a description of the genus Stenotrophomonas. Gram-negative, nonsporulating cells, about 0.5 by $1.5 \mu \mathrm{m}$, motile with several polar flagella (13). They may produce fimbriae (9). Poly- $\beta$-hydroxybutyrate granules are not accumulated, and exogenous polymer is not hydrolyzed. The colonies are smooth, glistening, with entire margin, white, grayish, or pale yellow.

Strains require methionine for growth, but this is not a universal property (16). Nitrate is reduced, but it is not used as an $\mathrm{N}$ source. Denitrification and egg yolk reaction are negative. Liquefaction of gelatin and lipolytic reaction (Tween 80 hydrolysis) are positive. Optimal growth temperature, $35^{\circ} \mathrm{C}$.

The nutritional spectrum is restricted. Of 145 organic compounds tested as the sole sources of carbon and energy, only 23 were used for growth (25). These include the disaccharides maltose, lactose, trehalose, and cellobiose and the glucoside salicin. Growth on lactose is poor, probably because of the inability to use galactose. Few fatty acids and amino acids were used for growth. None of the polyalcohols, aromatic compounds, or amines were used (25). Freshly isolated strains were found to use hydrocarbons, but the property was lost after subcultivation in common laboratory media $(14,15)$.

Isolated from assorted natural materials, human infections, and clinical materials. They are the most frequently isolated pseudomonads, after $P$. aeruginos $a$, in the clinical laboratory (11).

Characteristics useful for differentiating them from species of Xanthomonas are presented in Table 1 . Since only a single species of Stenotrophomonas is known, its properties are the same as for the genus. The type strain is ATCC 13637 (Hugh 810-2, NCIB 9203, NCTC 10257, NRC 729).

\section{REFERENCES}

1. Bradbury, J. F. 1984. Genus II. Xanthomonas, p. 199-210. In N. R. Krieg and J. G. Holt (ed.), Bergey's manual of systematic bacteriology, vol. 1. The Williams \& Wilkins Co., Baltimore.

2. Burkholder, W. H. 1930. The bacterial diseases of the bean. Cornell Agric. Exp. Stn. Mem. 127:1-88.

3. De Vos, P., and J. De Ley. 1983. Intra- and intergeneric similarities of Pseudomonas and Xanthomonas ribosomal ribonucleic acid cistrons. Int. J. Syst. Bacteriol. 33:487-509.

4. Dowson, W. J. 1939. On the systematic position and generic names of the Gram-negative bacterial plant pathogens. Zentralbl. Bakteriol. Parasitenkd. Infektionskr. Hyg. Abt. II 100: 177-193.

5. Dowson, W. J. 1957. Plant diseases due to bacteria, 2nd ed. University Press, Cambridge.

6. Dye, D. W. 1959. The genus Xanthomonas. Commonw. Phytopathol. News 5:1-3.

7. Dye, D. W., J. F. Bradbury, M. Goto, A. C. Hayward, R. A. Lelliott, and M. N. Schroth. 1980. International standards for naming pathovars of phytopathogenic bacteria and a list of pathovar names and pathotype strains. Rev. Plant Pathol. 59:153-168.

8. Dye, D. W., and R. A. Lelliott. 1974. Genus II. Xanthomonas Dowson 1939, 187, p. 243-249. In R. E. Buchanan and N. E. Gibbons (ed.), Bergey's manual of determinative bacteriology. The Williams \& Wilkins Co., Baltimore.

9. Fuerst, J. A., and A. C. Hayward. 1969. Surface appendages 
similar to fimbriae (pili) on Pseudomonas species. J. Gen. Microbiol. 58:227-237.

9a.Hayward, A. C. Personal communication.

10. Hugh, R. 1981. Pseudomonas maltophilia sp. nov., nom. rev. Int. J. Syst. Bacteriol. 31:195.

11. Hugh, R., and G. L. Gilardi. 1980. Pseudomonas, p. 288-317. In E. H. Lennette, A. Balows, W. J. Hausler, Jr., and J. P. Truant (ed.), Manual of clinical microbiology, 3rd ed. American Society for Microbiology, Washington, D.C.

12. Hugh, R., and E. Ryschenkow. 1960. An alcaligenes-like Pseudomonas species. Bacteriol. Proc. 1960:78.

13. Hugh, R., and E. Ryschenkow. 1961. Pseudomonas maltophilia, an Alcaligenes-like species. J. Gen. Microbiol. 26:123-132.

14. Iizuka, H., and K. Komagata. 1964. Microbiological studies on petroleum and natural gas. II. Determination of pseudomonads isolated from oil-brines and related materials. J. Gen. Appl. Microbiol. 10:223-231.

15. Iizuka, H., and K. Komagata. 1964. Microbiological studies on petroleum and natural gas. I. Determination of hydrocarbonutilizing bacteria. J. Gen. Appl. Microbiol. 10:207-221.

16. Ikemoto, S., K. Suzuki, T. Kaneko, and K. Komagata. 1980. Characterization of strains of Pseudomonas maltophilia which do not require methionine. Int. J. Syst. Bacteriol. 30:437-447.

17. Morris, R. E., D. A. Rees, G. Young, M. D. Walkinshaw, and A. Darke. 1977. Order-disorder transition for a bacterial polysaccharide in solution. A role for polysaccharide conformation in recognition between Xanthomonas and its plant host. J. Mol. Biol. 110:1-16.

18. Murata, N., and M. P. Starr. 1973. A concept of the genus Xanthomonas and its species in the light of segmental homology of deoxyribonucleic acids. Phytopathol. Z. 77:285-323.

19. Palleroni, N. J. 1981. Introduction to the family Pseudomonadaceae, p. 655-665. In M. P. Starr, H. Stolp, H. G. Trüper, A. Balows, and H. G. Schlegel (ed.), The prokaryotes: a handbook on habitats, isolation and identification of bacteria. SpringerVerlag, Berlin.

20. Palleroni, N. J. 1984. Genus I. Pseudomonas Migula 1894, p. 141-199. In N. R. Krieg and J. G. Holt (ed.), Bergey's manual of systematic bacteriology. The Williams \& Wilkins Co., Baltimore.

21. Palleroni, N. J. 1986. Taxonomy of the pseudomonads, p. 3-25. In J. R. Sokatch (ed.), The bacteria. A treatise on structure and function, vol. X. Academic Press, Inc., Orlando, Fla.

22. Palleroni, N. J. 1992. Introduction to the family Pseudomonadaceae, p. 3071-3085. In A. Balows, H. G. Trüper, M. Dworkin, W. Harder, and K.-H. Schleifer (ed.), The prokaryotes. A handbook on the biology of bacteria: ecophysiology, isolation, identification, applications. Springer-Verlag, New York.

23. Palleroni, N. J. 1992. Present situation of the taxonomy of the aerobic pseudomonads, p. 105-115. In E. Galli, S. Silver, and B. Witholt (ed.), Pseudomonas: molecular biology and biotechnology. American Society for Microbiology, Washington, D.C.

24. Palleroni, N. J., R. Kunisawa, R. Contopoulou, and M. Doudoroff. 1973. Nucleic acid homologies in the genus Pseudomonas. Int. J. Syst. Bacteriol. 23:333-339.

24a.Skerman, V. B. D., V. McGowan, and P. H. A. Sneath. 1980. Approved lists of bacterial names. Int. J. Syst. Bacteriol. 30:225-420.

25. Stanier, R. Y., N. J. Palleroni, and M. Doudoroff. 1966. The aerobic pseudomonads: a taxonomic study. J. Gen. Microbiol. 43:159-271.

26. Starr, M. P. 1981. The genus Xanthomonas, p. 742-763. In M. P. Starr, H. Stolp, H. G. Trüper, A. Balows, and H. G. Schlegel (ed.), The prokaryotes: a handbook on habitats, isolation and identification of bacteria. Springer-Verlag, Berlin.

27. Starr, M. P., C. L. Jenkins, L. B. Bussey, and A. G. Andrewes. 1977. Chemotaxonomic significance of the xanthomonadins, novel brominated aryl-polyene pigments produced by bacteria of the genus Xanthomonas. Arch. Microbiol. 113:1-9.

28. Swings, J., P. De Vos, M. Van den Mooter, and J. De Ley. 1983. Transfer of Pseudomonas maltophilia Hugh 1981 to the genus Xanthomonas as Xanthomonas maltophilia (Hugh 1981) comb. nov. Int. J. Syst. Bacteriol. 33:409-413.

29. Van den Mooter, M., and J. Swings. 1990. Numerical analysis of 295 phenotypic features of 266 Xanthomonas strains and related strains and an improved taxonomy of the genus. Int. J. Syst. Bacteriol. 40:348-369.

30. van den Mooter, M., J. Swings, M. De Cleene, F. Leyns, and J. De Ley. 1981. Susceptibility of Xanthomonas towards antibiotics in vitro. Med. Fac. Landbouww. Rijksuniv. Gent 46:787792.

31. Van Zyl, E., and P. L. Steyn. 1990. Differentiation of phytopathogenic $P_{\text {seudomonas }}$ and Xanthomonas species and pathovars by numerical taxonomy and protein gel electropherograms. Syst. Appl. Microbiol. 13:60-71.

32. Van Zyl, E., and P. L. Steyn. 1992. Reinterpretation of the taxonomic position of Xanthomonas maltophilia and taxonomic criteria in this genus. Request for an opinion. Int. J. Syst. Bacteriol. 42:193-198.

33. Vauterin, L., J. Swings, K. Kersters, M. Gillis, T. W. Mew, M. N. Schroth, N. J. Palleroni, D. C. Hildebrand, D. E. Stead, E. L. Civerolo, A. C. Hayward, H. Maraîte, R. E. Stall, A. K. Vidaver, and J. F. Bradbury. 1990. Towards an improved taxonomy of Xanthomonas. Int. J. Syst. Bacteriol. 40:312-316. 